\title{
Physical Facilities, Guest Relations Programs, Clinical Quality Assurance sebagai Variabel Patient Satisfaction menuju Patient Loyalty
}

\author{
Risdianto \\ Program Studi Manajemen, Fakultas Ekonomi, Universitas \\ Muhammadiyah Cirebon \\ risdianto@umc.ac.id
}

\begin{abstract}
Abstrak
Lima kriteria penentu kualitas jasa pelayanan yaitu reliability, responsiveness, assurance, emphaty, dan tangible dalam hubungannya dengan kepuasan. Dalam penelitian ini penulis mencoba menggunakan tiga variabel yang diungkapkan oleh Fish T. A, C. J Brown, K. Cannizaro dan B. Naftal yaitu physical facilities, guest relations programs dan clinical quality assurance sebagai variabel penentu patient satisfaction.

Physical facilities, guest relations programs dan clinical quality assurance secara bersama-sama mempunyai pengaruh yang berarti terhadap kepuasan pengguna jasa pelayanan rawat inap pada Rumah Sakit Pertamina Cilacap yang dibuktikan dengan hasil perhitungan yang menunjukkan bahwa $F$ hitung sebesar 103,7197 lebih besar dari F tabel sebesar 2,7253. 78,35 persen tingkat kepuasan yang diperoleh pengguna pelayanan jasa rawat inap pada Rumah Sakit pertamina Cilacap dipengaruhi oleh variable-variabel diatas, sedangkan pengaruh variabel lain yang tidak diteliti terhadap kepuasan pengguna pelayanan jasa rawat inap pada rumah sakit Pertamina Cilacap adalah sebesar 46,53 persen.
\end{abstract}

Guest relations programs secara parsial mempunyai pengaruh paling besar terhadap tingkat kepuasan pengguna jasa pelayanan rawat inap pada Rumah Sakit Pertamina Cilacap yang dibuktikan dengan hasil perhitungan yang menunjukkan bahwa koefisien jalur untuk guest relations programs sebesar 0,4298 lebih besar dibandingkan dengan koefisien jalur untuk physical facilities sebesar 0,2847 dan clinical quality assurance sebesar 
0,3403. Secara ekonomi dapat diartikan bahwa guest relations programs yang diperoleh pengguna pelayanan jasa secara langsung akan dapat berpengaruh pada kepuasan pasien sebesar 18,47 persen sedangkan pengaruh melalui hubungannya dengan physical facilities sebesar 7,82 persen dan pengaruh melalui hubungannya dengan clinical quality assurance sebesar 7,25 persen sehingga total guest relations programs akan dapat mempengaruhi tingkat kepuasan pengguna pelayanan jasa rawat inap sebesar 33,54 persen.

Kata kunci: physical facilities, guest relations programs, clinical quality assurance

\begin{abstract}
Five criteria of service quality determinants are reliability, responsiveness, assurance, empathy, and tangible in relation to satisfaction. In this study the author tries to use three variables expressed by Fish T. A, C. J Brown, K. Cannizaro and B. Naftal are physical facilities, guest relations programs and clinical quality assurance as variable determinant of patient satisfaction.
\end{abstract}

Physical facilities, guest relations programs and clinical quality assurance jointly have a significant influence on the satisfaction of users of inpatient services at Pertamina Hospital Cilacap as evidenced by the results of calculations that show that $F$ arithmetic of 103.7197 is greater than $F$ table of 2.7253. 78,35 percent satisfaction level obtained by user of inpatient service at Pertamina Hospital of Cilacap influenced by the above variables, while the influence of other variable not examined to the satisfaction of user of service of inpatient at Pertamina hospital of Cilacap is equal to 46,53 percent.

Guest relations programs partially have the most influence on the level of satisfaction of inpatient service users at Pertamina Hospital Cilacap as evidenced by the results of calculations indicating that the path coefficient for guest relations programs of 0.4298 is greater than the path coefficient for physical facilities of 0.2847 and clinical quality assurance of 0.3403 . 
Economically, it can be interpreted that guest relations programs obtained by service users will directly affect the patient satisfaction of 18.47 percent while the influence through its relationship with physical facilities of 7.82 percent and the influence through its relationship with clinical quality assurance of 7.25 Percent so that total guest relations programs will be able to affect the user satisfaction rate of inpatient services by 33.54 percent.

Key words: physical facilities, guest relations programs, clinical Quality assurance 


\section{PENDAHULUAN}

\section{Latar Belakang}

Pemerintah menyadari bahwa harus ada perbaikan yang dilakukan dalam hal penanganan bidang kesehatan, dalam hal ini salah satu infrastruktur yang sangat menunjang dan perlu diadakan perbaikan dalam pengelolaannya adalah rumah sakit karena selama ini rumah sakit bisa dianggap sebagai tolok ukur keberhasilan pemerintah dalam hal penanganan bidang kesehatan. Konsep pengelolaan rumah sakit selama ini dirasakan belum jelas karena pada saat itu segala sesuatu yang berhubungan dengan rumah sakit dikendalikan secara terpusat atau berperan hanya sebagai pelaksana dari suatu kebijaksanaan yang telah ditetapkan oleh pusat, tanpa ada kesempatan bagi rumah sakit tersebut untuk mengembangkan diri. Akibat dari hal tersebut adalah terhadap kinerja dari rumah sakit terutama terhadap pelayanan yang diberikan kepada pengguna jasa pelayanan rumah sakit.

Menurut Parasuraman yang dikutip oleh Fandy Tjiptono, dalam memberikan jasa pelayanan yang baik kepada pelanggan terdapat lima kriteria penentu kualitas jasa pelayanan yaitu kehandalan (reliability), ketanggapan (responsiveness), kepastian (assurance), empati (emphaty), dan tampilan fisik (tangible). ${ }^{1}$ Lima kriteria penentu di atas dalam hubungannya dengan kepuasan dan sudah sering kita ketahui. Dalam penelitian ini lebih menekankan pada 3 (tiga) variabel yang diungkapkan oleh Fish T. A, C. J Brown, K. Cannizaro dan B. Naftal yaitu

${ }^{I}$ Fandy Tjiptono. 1994. Strategi pemasaran. Andi offset. Yogyakarta. physical facilities, guest relations programs dan clinical quality assurance. $^{2}$

Penelitian pendahuluan yang dilakukan terhadap 20 orang pasien pengguna jasa perawatan di ruang VIP, ruang perawatan kelas I, ruang perawatan kelas II dan ruang perawatan kelas III di Rumah Sakit Pertamina Cilacap diperoleh data bahwa 19 orang (95 persen) menyatakan merasa puas dengan pelayanan yang diberikan sedangkan 1 orang (5 persen) menyatakan kurang puas dengan pelayanan yang diberikan. Data 19 orang yang menyatakan puas tersebut terdiri dari 6 orang $(31,58$ persen) menyatakan bahwa kepuasan tersebut terutama karena faktor-faktor physical facilities, 9 orang (47,37 persen) menyatakan bahwa kepuasan tersebut terutama karena faktor-faktor guest relations programs, 4 orang $(21,05$ persen) menyatakan bahwa kepuasan tersebut terutama karena faktor-faktor clinical quality assurance. Maka rumusan masalah dalam penelitian ini adalah:

1. Apakah variabel physical facilities, guest relations programs, clinical quality assurance mempunyai pengaruh terhadap tingkat kepuasan pasien pada Rumah Sakit Pertamina Cilacap?

2. Diantara tiga variabel tersebut, variabel manakah yang mempunyai pengaruh paling besar terhadap tingkat kepuasan pasien pada Rumah Sakit Pertamina Cilacap?

\footnotetext{
${ }^{2}$ Fish T. A et. al., 1990. Creating patient satisfaction and loyalty. Journal of health care marketing.
} 
Studi Literatur ${ }^{3}$

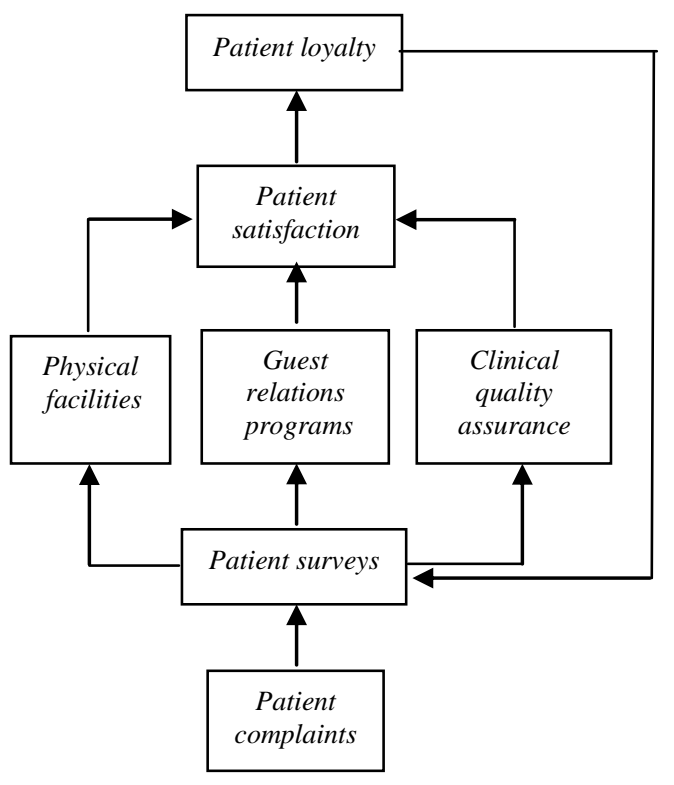

Dalam jurnal yang dikemukakan oleh Fish T.A menjelaskan hingga pada tahap loyalitas pasien, dalam penelitian ini penulis hanya sampai pada tahap kepuasan pasien (patient satisfaction).

\section{Kerangka Pemikiran}

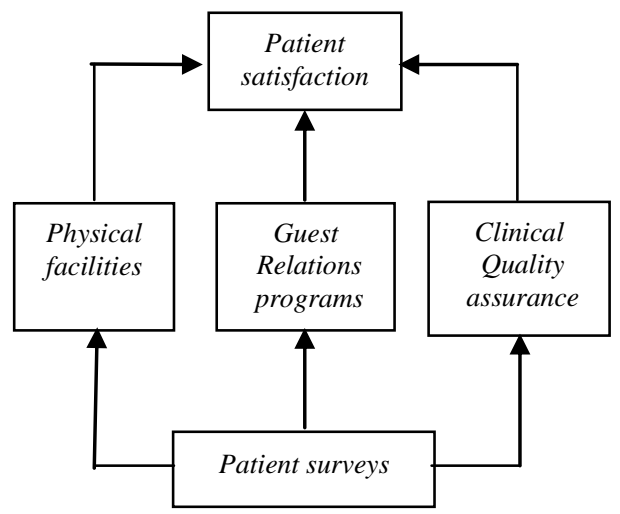

Rumah sakit sebagai unit usaha dan layaknya sebuah perusahaan pada umumnya akan maju dengan pesat jika mereka mampu

${ }^{3}$ Fish T. A et. al, 1990. Creating Patient Satisfaction and Loyalty. Journal of Health Care Marketing. menciptakan

kepuasan

(satisfaction) dan kesetiaan (loyalty) pelanggan. Pelanggan di rumah sakit terdiri dari berbagai macam pelanggan diantaranya tenaga medis, pemilik (penanggung biaya), pasien dan sebagainya, tetapi bagaimana pun kepuasan dan kesetiaan pasien sebagai pengguna akhir (end user) pelayanan rumah sakit adalah unsur pokok diantara kepuasan dan kesetiaan yang lain, lagi pula pendapatan terbesar rumah sakit adalah berasal dari pasien ${ }^{4}$.

$$
\text { Pelanggan dalam }
$$

menggunakan atau memilih suatu jenis jasa pelayanan dipengaruhi oleh faktor-faktor yaitu komunikasi dari mulut ke mulut, kebutuhan pribadi (promosi dari perusahaan) dan pengalaman masa lalunya yang kesemuanya membentuk suatu harapan tertentu dalam benak pelanggan terhadap kualitas pelayanan yang akan di terima.

\section{Hipotesis}

1. Physical facilities, guest relations programs dan clinical quality assurance secara bersama-sama mempunyai pengaruh yang berarti terhadap tingkat kepuasan pasien.

2. Guest relations programs mempunyai pengaruh paling besar dibandingkan dengan physical facilities dan clinical quality assurance terhadap tingkat kepuasan pasien.

\section{Metode Penelitian}

Pengambilan sampel dilakukan dengan metode Stratified random sampling yaitu suatu populasi yang heterogen dibagi dalam lapisan atau strata yang seragam dan dari setiap

\footnotetext{
${ }^{4}$ Fish T. A et. al., 1990. Creating Patient Satisfaction and Loyalty. Journal of Health Care Marketing.
} 
lapisan atau strata yang heterogen diambil sampel secara acak.

1. Definisi operasional variabel

a. Kepuasan pasien (Y) yaitu tingkat perasaan seseorang setelah membandingkan kinerja atau hasil yang dirasakannya dengan harapannya, sedangkan pasien adalah seseorang yang dirawat karena suatu penyakit dan mendapatkan pelayanan rawat inap. Indikator yang bisa digunakan dalam hal ini adalah:

1) Pasien menerima pelayanan sesuai dengan kelas yang ia pilih.

2) Pasien menerima perlakuan yang sama terhadap diagnosis medis yang diberikan.

b. Physical facilities $\left(\mathrm{X}_{1}\right)$ yaitu penampilan dan kemampuan sarana dan prasarana fisik yang dapat diandalkan dan menunjang kinerja. Indikator yang bisa digunakan dalam hal ini adalah:

1) Peralatan dan perlengkapan yang dipergunakan lengkap.

2) Fasilitas yang terdapat dalam ruangan dapat dipergunakan dengan baik.

3) Kondisi ruang perawatan terawat dengan baik.

4) Penampilan paramedis dalam menjalankan tugas yang baik

c. Guest relations programs $\left(\mathrm{X}_{2}\right)$ yaitu program penanganan dan penerimaan pasien yang handal, tanggap dan mampu memberikan perhatian yang bersifat individual atau secara pribadi kepada pasien atau pelanggan. Indikator yang bisa digunakan dalam hal ini adalah:

1) Pengunjung (calon pasien) diperlakukan sama.

2) Pelayanan kepada pasien selalu berusaha tepat waktu.

3) Keramahan paramedis dalam menyambut pengunjung dan pasien.

4) Kesediaan dokter dalam memberikan penjelasan tentang riwayat penyakit pasien.

5) Pelayanan yang diberikan berupaya untuk memahami pasien secara pribadi.

d. Clinical quality assurance $\left(\mathrm{X}_{3}\right)$ yaitu pengetahuan dan kemampuan para karyawan dalam melaksanakan tugas dan menjamin kinerja yang baik sehingga memberikan kepercayaan dan keyakinan kepada para pasien. Indikator yang bisa digunakan dalam hal ini adalah:

1) Peralatan yang digunakan adalah peralatan yang modern dan terjamin.

2) Kecakapan dan pengetahuan yang dimiliki staf rumah sakit baik.

3) Ketelitian staf medis dalam diagnosis medis.

2. Penentuan ukuran sampel

Sampel sebaiknya diambil sebanyak mungkin dari populasi, untuk populasi antara 10-100 sebaiknya diambil 100 persen, untuk populasi antara 100-200 diambil 7080 persen dan seterusnya. Jadi dengan berdasarkan hal tersebut maka penulis 
mengambil sampel dalam penelitian ini adalah sebesar 70 persen dari populasi, pengambilan sampel sebanyak 70 persen dari populasi ini penulis anggap cukup mewakili dan dengan berbagai pertimbangan lainnya. $^{5}$

Penelitian ini hanya dibatasi pada ruang perawatan VIP, ruang perawatan kelas I, ruang perawatan kelas II dan ruang perawatan kelas III, dari data di atas diketahui jumlah pasien pada ruang perawatan tersebut adalah sebanyak 128 orang, berdasarkan ketentuan pengambilan sampel di atas yaitu diambil sebanyak 70 persen dari populasi maka diperoleh $0,70 \times 128$ orang $=89,6$ orang atau 90 orang.

3. Uji validitas dan reliabilitas terhadap kuesioner
a. Uji validitas
Merupakan
pengujian
terhadap alat pengukur sejauh mana mampu mengukur apa yang ingin diukur dengan menggunakan
korelasi
Product Moment.

b. Uji reliabilitas

Untuk menghitung indeks reliabilitas digunakan teknik belah dua.

4. Analisa perubahan tingkat pengukuran

untuk memenuhi salah satu syarat dalam perhitungan analisa jalur yang menghendaki data dalam skala pengukuran interval maka data dalam skala ordinal perlu ditingkatkan ke dalam skala pengukuran interval. Teknik yang digunakan untuk perubahan

5 Kartini Kartono, 1996. Pengantar Metodologi Riset Sosial. Mandar Maju. Bandung tingkat pengukuran ini adalah Methode of Successive Interval dengan langkah-langkah sebagai berikut: $^{6}$

\section{a. Analisa jalur (path analysis)}

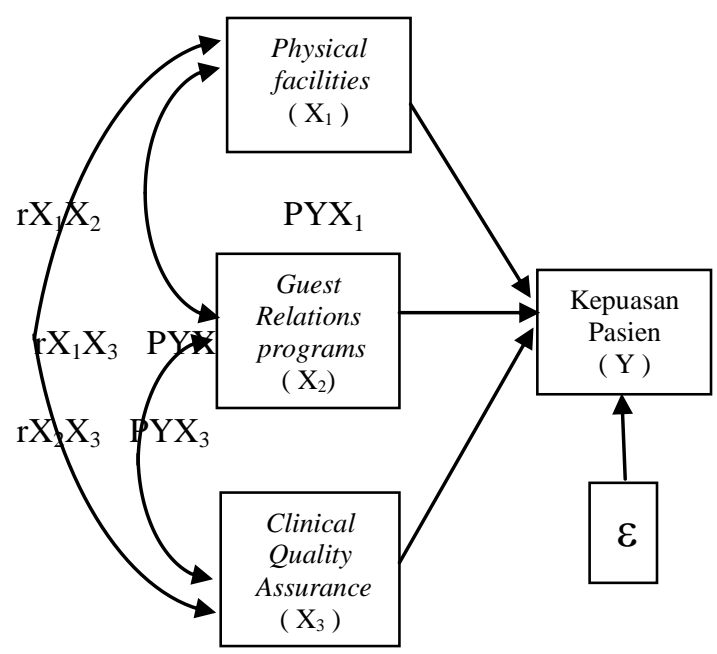

\section{Gambar Hubungan struktural antar variabel $X_{1}, X_{2}, X_{3}$, terhadap $Y$}

b. menghitung matriks korelasi antar variabel

c. menghitung matriks korelasi antar variabel bebas.

d. menghitung matriks invers korelasi antar variabel bebas.

e. menghitung koefisien jalur PYXi, $=1,2,3$

f. menghitung $\mathrm{R}^{2} \mathrm{Y}\left(\mathrm{X}_{1}, \mathrm{X}_{2}, \mathrm{X}_{3}\right)$ yaitu koefisien yang menyatakan determinasi total $\mathrm{X}_{1}, \mathrm{X}_{2}, \mathrm{X}_{3}$ terhadap Y.

g. mengetahui besarnya pengaruh variabel-variabel lainnya terhadap Y dan diluar Xi.

h. menguji keberartian koefisien jalur secara keseluruhan digunakan uji F.

\footnotetext{
Al Rasyid, Harun, 1994. Teknik pengambilan sampel dan penyusunan skala. Program pasca sarjana Universitas Padjadjaran. Bandung.
} 


$$
F=\frac{(n-k-1) R^{2} Y X_{1} X_{2} X_{3}}{k\left(1-R^{2} Y\left(X_{1} X_{2} X_{3}\right)\right)}
$$

Kriteria pengujian hipotesis:

Ho: $\mathrm{PYX}_{1}=\mathrm{PYX}_{2}=\mathrm{PYX}_{3}=0$, berarti besarnya pengaruh physical facilities, guest relations programs dan clinical quality assurance terhadap variabel kepuasan pasien tidak nyata secara keseluruhan.

Ha: sekurang-kurangnya ada satu $\mathrm{PYX}_{1}, \mathrm{PYX}_{2}, \mathrm{PYX}_{3} \neq 0$, berarti besarnya pengaruh variabel physical facilities, guest relations programs dan clinical quality assurance terhadap variabel kepuasan pasien secara keseluruhan adalah nyata.

Dengan derajat kebebasan $(\mathrm{df})=\mathrm{k}$ dan $(\mathrm{n}-\mathrm{k}-1)$, dan tingkat kepercayaan 95\% ( $\alpha=0,05)$ maka:

Ho diterima jika $\mathrm{F}$ hitung $\leq \mathrm{F}$ tabel Ho ditolak jika $\mathrm{F}$ hitung $>\mathrm{F}$ tabel

i. Untuk menguji keberartian koefisien jalur secara parsial digunakan uji $t$ dengan menggunakan rumus sebagai berikut:

$$
t=\sqrt{\frac{P Y X i}{\left(1-R^{2} Y x i\right) C i i}}
$$

Kriteria pengujian:

Ho : $\mathrm{PYX}_{1}=\mathrm{PYX}_{2}=\mathrm{PYX}_{3}=0$, berarti besarnya pengaruh variabel physical facilities, guest relations programs dan clinical quality assurance terhadap kepuasan pasien tidak nyata secara parsial sehingga diagram jalur perlu diadakan perubahan.

$\mathrm{Ha}: \mathrm{PYX}_{1}, \mathrm{PYX}_{2}, \mathrm{PYX}_{3} \neq 0$, berarti besarnya pengaruh variabel physical facilities, guest relations programs dan clinical quality assurance terhadap kepuasan pasien nyata secara parsial.

Dengan derajat kebebasan $(\mathrm{df})=\mathrm{k}$ dan $(\mathrm{n}-\mathrm{k}-1)$ dan tingkat kepercayaan $\quad 95 \% \quad(\alpha=0,05)$ maka:

Ho diterima jika $\mathrm{t}$ hitung $\leq \mathrm{t}$ tabel Ho ditolak jika t hitung $>\mathrm{t}$ tabel

j. Koefisien jalur adalah koefisien yang tidak mempunyai satuan, oleh karena itu bila dihubungkan dengan hipotesis kedua, bisa sekaligus kita ambil kesimpulan bahwa semakin besar koefisien jalur maka secara relatif semakin besar pula pengaruh yang diberikan variabel tersebut terhadap Y. Berdasarkan hal tersebut maka dapat ditentukan kriteria pengujian hipotesis kedua sebagai berikut:

Ho diterima jika PYX2 > PYX1, PYX3

Ho ditolak jika PYX2 < PYX1, PYX3

\section{PEMBAHASAN}

Gambaran karakteristik sosial ekonomi dari responden melalui jawaban atas kuisioner yang diberikan.

Tabel 1 Distribusi karakteristik responden berdasarkan usia

\begin{tabular}{cccc}
\hline no & $\begin{array}{c}\text { Usia } \\
\text { (tahun) }\end{array}$ & $\begin{array}{c}\text { Jumlah } \\
\text { (orang) }\end{array}$ & Persentase \\
\hline $\mathbf{1}$ & $<20$ & 4 & 4.44 \\
$\mathbf{2}$ & $20-29$ & 24 & 26.67 \\
$\mathbf{3}$ & $30-39$ & 25 & 27.78 \\
$\mathbf{4}$ & $40-49$ & 27 & 30.00 \\
$\mathbf{5}$ & $>50$ & 10 & 11.11 \\
Jumlah & & 90 & 100.00 \\
\hline
\end{tabular}

Tabel 2 Distribusi karakteristik responden berdasarkan jenis kelamin

\begin{tabular}{cccc}
\hline No & $\begin{array}{c}\text { Jenis } \\
\text { Kelamin }\end{array}$ & $\begin{array}{c}\text { Jumlah } \\
\text { (orang) }\end{array}$ & Persentase \\
\hline $\mathbf{1}$ & Laki - laki & 52 & 57.78 \\
$\mathbf{2}$ & Perempuan & 38 & 42.22 \\
Jumlah & & 90 & 100.00 \\
\hline
\end{tabular}


Tabel 3 Distribusi karakteristik responden berdasarkan tingkat pendidikan

\begin{tabular}{cccc}
\hline no & $\begin{array}{c}\text { Tingkat } \\
\text { pendidikan }\end{array}$ & $\begin{array}{c}\text { Jumlah } \\
\text { (orang) }\end{array}$ & Persentase \\
\hline $\mathbf{1}$ & SD & - & - \\
$\mathbf{2}$ & SMP & 2 & 2.22 \\
$\mathbf{3}$ & SMA & 23 & 25.56 \\
$\mathbf{4}$ & $\begin{array}{c}\text { Perguruan } \\
\text { tinggi }\end{array}$ & .65 & 72.22 \\
Jumlah & & 90 & 100 \\
\hline
\end{tabular}

Tabel 4 Distribusi karakteristik responden berdasarkan tingkat penghasilan

\begin{tabular}{cccc}
\hline no & $\begin{array}{c}\text { Penghasilan } \\
\text { (juta rupiah) }\end{array}$ & $\begin{array}{c}\text { Jumlah } \\
\text { (orang) }\end{array}$ & Persentase \\
\hline $\mathbf{1}$ & $1.000-1.250$ & 26 & 28.89 \\
$\mathbf{2}$ & $1.250 .001-1.500$ & 31 & 34.44 \\
$\mathbf{3}$ & $1.500 .001-1.750$ & 14 & 15.56 \\
$\mathbf{4}$ & $1.750 .001-2.000$ & 11 & 12.22 \\
$\mathbf{5}$ & $<2.000$ & 8 & 8.89 \\
Jumlah & & 90 & 100 \\
\hline
\end{tabular}

Tabel 5 Distribusi karakteristik responden berdasarkan pekerjaan

\begin{tabular}{cccc}
\hline no & pekerjaan & $\begin{array}{c}\text { Jumlah } \\
\text { (orang) }\end{array}$ & $\begin{array}{c}\text { persentas } \\
\text { e }\end{array}$ \\
\hline $\mathbf{1}$ & Pegawai negeri & 30 & 33.33 \\
$\mathbf{2}$ & Pegawai swasta & 42 & 46.67 \\
$\mathbf{3}$ & Wiraswasta & 11 & 12.22 \\
$\mathbf{4}$ & Lain -lain & 7 & 7.78 \\
Jumlah & & 90 & 100 \\
\hline
\end{tabular}

\section{Uji Validitas dan Reliabilitas}

Tabel 6 Uji validitas dan reliabilitas untuk

\begin{tabular}{lllllll}
\multicolumn{7}{c}{ variabel patient satisfaction $(\mathbf{Y})$} \\
\hline it & Koefisie & $\mathbf{r}$ & $\mathbf{n}=$ & keter & ryy & $\begin{array}{l}\text { reliab } \\
\text { i }\end{array}$ \\
nkorelas & tabe & $\mathbf{9 0}$ & anga & & ilitas \\
$\mathbf{m}$ & $\mathbf{i}$ & $\mathbf{l}$ & $\mathbf{0 . 0 1}$ & $\mathbf{n}$ & & \\
& & $\mathbf{0 . 0 5}$ & & & & \\
\hline $\mathbf{1}$ & $0.8170^{*}$ & 0.20 & 0.27 & Valid & 0.16 & 0.282 \\
& $*$ & 7 & 0 & & 47 & 9 \\
$\mathbf{2}$ & $0.7033^{*}$ & 0.20 & 0.27 & valid & & \\
& $*$ & 7 & 0 & & & \\
\hline
\end{tabular}

$* *$ = sangat nyata

$*$ = nyata

Tabel 7 Uji validitas dan reliabilitas untuk physical facilities $\left(\mathrm{X}_{1}\right)$

\begin{tabular}{|c|c|c|c|c|c|c|}
\hline $\begin{array}{l}\text { it } \\
\text { e } \\
\text { m }\end{array}$ & $\begin{array}{l}\text { Koefisie } \\
\text { n } \\
\text { korelasi }\end{array}$ & $\begin{array}{l}r \\
\text { tabe } \\
1 \\
0.05 \\
\end{array}$ & $\begin{array}{l}\mathbf{n}= \\
90 \\
0.01\end{array}$ & $\begin{array}{l}\text { keter } \\
\text { anga } \\
\text { n }\end{array}$ & $\mathbf{r x x}_{1}$ & $\begin{array}{l}\text { relia } \\
\text { bilit } \\
\text { as }\end{array}$ \\
\hline 1 & $\begin{array}{l}0.4344 * \\
*\end{array}$ & $\begin{array}{l}0.20 \\
7\end{array}$ & $\begin{array}{l}0.27 \\
0\end{array}$ & valid & $\begin{array}{l}0.526 \\
9\end{array}$ & $\begin{array}{l}0.69 \\
02\end{array}$ \\
\hline 2 & $\begin{array}{l}0.4191 * \\
*\end{array}$ & $\begin{array}{l}0.20 \\
7\end{array}$ & $\begin{array}{l}0.27 \\
0\end{array}$ & Valid & & \\
\hline 3 & $\begin{array}{l}0.5126 * \\
*\end{array}$ & $\begin{array}{l}0.20 \\
7\end{array}$ & $\begin{array}{l}0.27 \\
0\end{array}$ & Valid & & \\
\hline 4 & $\begin{array}{l}0.5816^{*} \\
*\end{array}$ & $\begin{array}{l}0.20 \\
7\end{array}$ & $\begin{array}{l}0.27 \\
0\end{array}$ & Valid & & \\
\hline 5 & $\begin{array}{l}0.5756^{*} \\
*\end{array}$ & $\begin{array}{l}0.20 \\
7\end{array}$ & $\begin{array}{l}0.27 \\
0\end{array}$ & Valid & & \\
\hline
\end{tabular}

\begin{tabular}{lllll}
\hline $\mathbf{6}$ & $0.5604 *$ & 0.20 & 0.27 & Valid \\
& $*$ & 7 & 0 & \\
7 & $0.4820 *$ & 0.20 & 0.27 & Valid \\
& $*$ & 7 & 0 & \\
$\mathbf{8}$ & $0.4321 *$ & 0.20 & 0.27 & valid \\
& $*$ & 7 & 0 & \\
\hline$* *$ & $=$ sangat nyata & & \\
$*$ & $=$ nyata
\end{tabular}

Tabel 8 Uji validitas dan reliabilitas untuk guest relations programs $\left(\mathrm{X}_{2}\right)$

\begin{tabular}{|c|c|c|c|c|c|c|}
\hline it & $\begin{array}{l}\text { Koefisi } \\
\text { en } \\
\text { korelas } \\
\text { i }\end{array}$ & $\begin{array}{l}\mathbf{r} \\
\text { tab } \\
\text { el } \\
0.05 \\
\end{array}$ & $\begin{array}{l}\mathbf{n}=9 \\
\mathbf{0} \\
0.01\end{array}$ & $\begin{array}{l}\text { ket } \\
\text { era } \\
\text { nga } \\
\text { n }\end{array}$ & $\mathbf{r x x} 2$ & $\begin{array}{l}\text { reli } \\
\text { abil } \\
\text { itas }\end{array}$ \\
\hline 1 & $\begin{array}{l}0.4299 * \\
*\end{array}$ & $\begin{array}{l}0.20 \\
7\end{array}$ & $\begin{array}{l}0.27 \\
0\end{array}$ & $\begin{array}{l}\text { vali } \\
\text { d }\end{array}$ & 0.3083 & $\begin{array}{l}0.47 \\
13\end{array}$ \\
\hline 2 & $\begin{array}{l}0.2625 * \\
*\end{array}$ & $\begin{array}{l}0.20 \\
7\end{array}$ & $\begin{array}{l}0.27 \\
0\end{array}$ & $\begin{array}{l}\text { vali } \\
\text { d }\end{array}$ & & \\
\hline 3 & $\begin{array}{l}0.6522 * \\
*\end{array}$ & $\begin{array}{l}0.20 \\
7\end{array}$ & $\begin{array}{l}0.27 \\
0\end{array}$ & $\begin{array}{l}\text { vali } \\
\text { d }\end{array}$ & & \\
\hline 4 & $\begin{array}{l}0.6755 * \\
*\end{array}$ & $\begin{array}{l}0.20 \\
7\end{array}$ & $\begin{array}{l}0.27 \\
0\end{array}$ & $\begin{array}{l}\text { vali } \\
\text { d }\end{array}$ & & \\
\hline 5 & $\begin{array}{l}0.5293 * \\
*\end{array}$ & $\begin{array}{l}0.20 \\
7\end{array}$ & $\begin{array}{l}0.27 \\
0\end{array}$ & $\begin{array}{l}\text { vali } \\
\text { d }\end{array}$ & & \\
\hline 6 & $\begin{array}{l}0.4761 * \\
*\end{array}$ & $\begin{array}{l}0.20 \\
7 \\
\end{array}$ & $\begin{array}{l}0.27 \\
0 \\
\end{array}$ & $\begin{array}{l}\text { vali } \\
\mathrm{d}\end{array}$ & & \\
\hline
\end{tabular}

Tabel 9 Uji validitas dan reliabilitas untuk clinical quality assurance $\left(\mathrm{X}_{3}\right)$

\begin{tabular}{|c|c|c|c|c|c|c|}
\hline $\begin{array}{l}\text { ite } \\
\text { m }\end{array}$ & $\begin{array}{l}\text { Koefis } \\
\text { ien } \\
\text { korela } \\
\text { si }\end{array}$ & $\begin{array}{l}\mathbf{r} \\
\text { Tab } \\
\text { el } \\
0.05\end{array}$ & $\begin{array}{l}\text { n=9 } \\
0 \\
0.01\end{array}$ & $\begin{array}{l}\text { kete } \\
\text { rang } \\
\text { an }\end{array}$ & $\mathbf{r x x}_{3}$ & $\begin{array}{l}\text { reli } \\
\text { abil } \\
\text { itas }\end{array}$ \\
\hline 1 & $\begin{array}{l}0.4716 \\
* *\end{array}$ & $\begin{array}{l}0.20 \\
7\end{array}$ & $\begin{array}{l}0.27 \\
0\end{array}$ & valid & $\begin{array}{l}0.467 \\
7\end{array}$ & $\begin{array}{l}0.63 \\
73\end{array}$ \\
\hline 2 & $\begin{array}{l}0.6573 \\
* *\end{array}$ & $\begin{array}{l}0.20 \\
7\end{array}$ & $\begin{array}{l}0.27 \\
0\end{array}$ & valid & & \\
\hline 3 & $\begin{array}{l}0.6017 \\
* *\end{array}$ & $\begin{array}{l}0.20 \\
7\end{array}$ & $\begin{array}{l}0.27 \\
0\end{array}$ & valid & & \\
\hline 4 & $\begin{array}{l}0.2735 \\
* *\end{array}$ & $\begin{array}{l}0.20 \\
7\end{array}$ & $\begin{array}{l}0.27 \\
0\end{array}$ & valid & & \\
\hline 5 & $\begin{array}{l}0.5705 \\
* *\end{array}$ & $\begin{array}{l}0.20 \\
7\end{array}$ & $\begin{array}{l}0.27 \\
0\end{array}$ & valid & & \\
\hline 6 & $\begin{array}{l}0.7581 \\
* *\end{array}$ & $\begin{array}{l}0.20 \\
7\end{array}$ & $\begin{array}{l}0.27 \\
0\end{array}$ & valid & & \\
\hline
\end{tabular}


Analisis Jalur (Path Analysis)

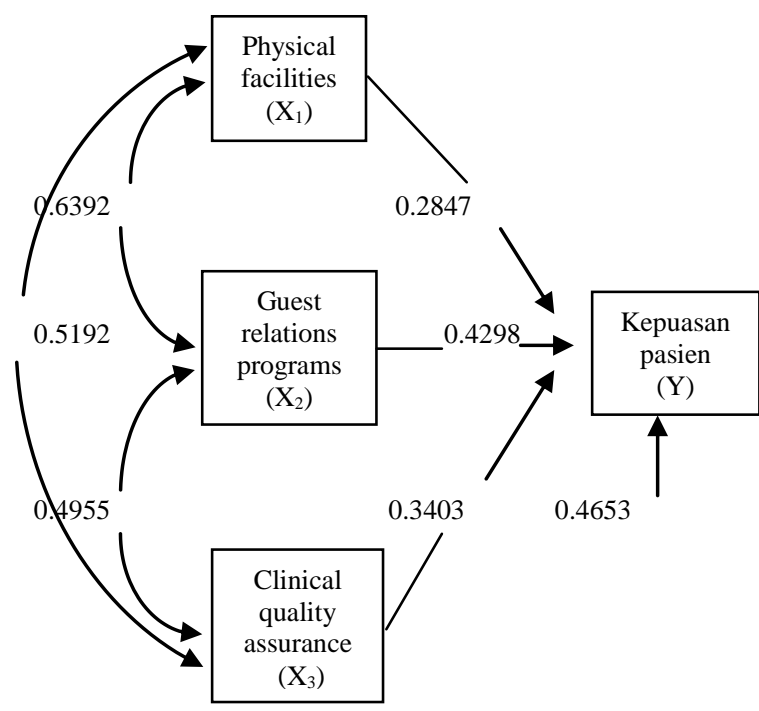

Gambar Hubungan struktural antar
variabel $X_{1}, X_{2}$, dan $X_{3}$ terhadap $Y$

a. Pengaruh physical facilities $\left(\mathrm{X}_{1}\right)$ terhadap kepuasan pasien (Y)

1) Pengaruh langsung

$$
\begin{aligned}
\mathrm{Y} \leftarrow \mathrm{X}_{1} \rightarrow \mathrm{Y}= & \mathrm{PYX}_{1} \times \mathrm{PYX}_{1} \\
& =0,2847 \times 0,2847 \\
& =0,0810
\end{aligned}
$$

2) Pengaruh tak langsung

a) melalui $X_{2}$

$$
\begin{aligned}
\mathrm{Y} \leftarrow \mathrm{X}_{1} \Omega \mathrm{X}_{2} \rightarrow \mathrm{Y} & =\mathrm{PYX}_{1} \times \mathrm{rX}_{1} \mathrm{X}_{2} \times \mathrm{PYX}_{2} \\
& =0,2847 \times 0,6392 \times 0,4298 \\
& =0,0782
\end{aligned}
$$

b) melalui $X_{3}$

$$
\begin{aligned}
\mathrm{Y} \leftarrow \mathrm{X}_{1} \Omega \mathrm{X}_{3} \rightarrow \mathrm{Y} & =\mathrm{PYX}_{1} \times \mathrm{rX}_{1} \mathrm{X}_{3} \times \mathrm{PYX}_{3} \\
& =0,2847 \times 0,5192 \times 0,3403 \\
& =0,0503
\end{aligned}
$$

Secara ekonomis dapat diartikan bahwa variabel physical facilities $\left(\mathrm{X}_{1}\right)$ secara langsung berpengaruh pada kepuasan pasien (Y) sebesar 8,10 persen, sedangkan pengaruh variabel physical facilities $\left(\mathrm{X}_{1}\right)$ terhadap kepuasan pasien $(\mathrm{Y})$ melalui variabel guest relations programs $\left(\mathrm{X}_{2}\right)$ sebesar 7,82 persen dan yang melalui variabel clinical quality assurance $\left(\mathrm{X}_{3}\right)$ sebesar 5,03 persen sehingga secara total pengaruh variabel physical facilities $\left(\mathrm{X}_{1}\right)$ terhadap kepuasan pasien (Y) sebesar 20,95 persen artinya perubahan tingkat kepuasan pasien dapat dijelaskan oleh variabel physical facilities $\left(\mathrm{X}_{1}\right)$ sebesar 20,95 persen.

b. Pengaruh guest relations programs $\left(\mathrm{X}_{2}\right)$ terhadap kepuasan pasien $(\mathrm{Y})$

1) Pengaruh langsung

$$
\begin{aligned}
\mathrm{Y} \leftarrow \mathrm{X}_{2} \rightarrow \mathrm{Y} & =\mathrm{PYX}_{2} \times \mathrm{PYX}_{2} \\
& =0,4298 \times 0,4298 \\
& =0,1847
\end{aligned}
$$

2) Pengaruh tak langsung

a) melalui $X_{1}$

$$
\begin{aligned}
\mathrm{Y} \leftarrow \mathrm{X}_{2} \Omega \mathrm{X}_{1} \rightarrow \mathrm{Y} & =\mathrm{PYX}_{2} \times \mathrm{rX}_{1} \mathrm{X}_{2} \times \mathrm{PYX}_{1} \\
& =0,4298 \times 0,6392 \times 0,2847 \\
& =0,0782
\end{aligned}
$$

b) melalui $X_{3}$

$$
\begin{aligned}
\mathrm{Y} \leftarrow \mathrm{X}_{2} \Omega X_{3} \rightarrow \mathrm{Y} & =\mathrm{PYX}_{2} \times \mathrm{rX}_{2} \mathrm{X}_{3} \times \mathrm{PYX}_{3} \\
& =0,4298 \times 0,4955 \times 0,3403 \\
& =0,0725
\end{aligned}
$$

Secara ekonomis dapat diartikan bahwa variabel guest relations programs $\left(\mathrm{X}_{2}\right)$ secara langsung berpengaruh pada kepuasan pasien (Y) sebesar 18,47 persen, sedangkan pengaruh variabel guest relations programs $\left(\mathrm{X}_{2}\right)$ terhadap kepuasan pasien $(\mathrm{Y})$ melalui variabel physical facilities $\left(\mathrm{X}_{1}\right)$ sebesar 7,82 persen dan yang melalui variabel clinical quality assurance $\left(\mathrm{X}_{3}\right)$ sebesar 7,25 persen sehingga secara total pengaruh variabel guest relations programs $\left(\mathrm{X}_{2}\right)$ terhadap kepuasan pasien (Y) sebesar 33,54 persen artinya perubahan tingkat kepuasan pasien dapat dijelaskan oleh variabel guest relations programs $\left(\mathrm{X}_{2}\right)$ sebesar 33,54 persen.

c. Pengaruh clinical quality assurance $\left(\mathrm{X}_{3}\right)$ terhadap kepuasan pasien $(\mathrm{Y})$ 
1) Pengaruh langsung

$$
\begin{aligned}
\mathrm{Y} \leftarrow \mathrm{X}_{3} \rightarrow \mathrm{Y} & =\mathrm{PYX}_{3} \times \mathrm{PYX}_{3} \\
& =0,3403 \times 0,3403 \\
& =0,1158
\end{aligned}
$$

2) Pengaruh tak langsung

a) melalui $X_{1}$

$$
\begin{aligned}
\mathrm{Y} \leftarrow \mathrm{X}_{3} \Omega \mathrm{X}_{1} \rightarrow \mathrm{Y} & =\mathrm{PYX}_{3} \times \mathrm{rX}_{1} \mathrm{X}_{3} \times \mathrm{PYX}_{1} \\
& =0,3403 \times 0,5192 \times 0,2847 \\
& =0,0503
\end{aligned}
$$

b) melalui $X_{2}$

$$
\begin{aligned}
\mathrm{Y} \leftarrow \mathrm{X}_{3} \Omega \mathrm{X}_{2} \rightarrow \mathrm{Y} & =\mathrm{PYX}_{3} \times \mathrm{rX}_{2} \mathrm{X}_{3} \times \mathrm{PYX}_{2} \\
& =0,3403 \times 0,4955 \times 0,4298 \\
& =0,0725
\end{aligned}
$$

Secara ekonomis dapat diartikan bahwa variabel clinical quality assurance $\quad\left(\mathrm{X}_{3}\right)$ secara langsung berpengaruh pada kepuasan pasien (Y) sebesar 11,58 persen, sedangkan pengaruh variabel clinical quality assurance $\left(\mathrm{X}_{3}\right)$ terhadap kepuasan pasien (Y) melalui variabel physical facilities $\left(\mathrm{X}_{1}\right)$ sebesar 5,03 persen dan yang melalui variabel guest relations programs $\left(\mathrm{X}_{2}\right)$ sebesar 7,25 persen sehingga secara total pengaruh variabel clinical quality assurance $\left(\mathrm{X}_{3}\right)$ terhadap kepuasan pasien (Y) sebesar 23,85 persen artinya perubahan tingkat kepuasan pasien dapat dijelaskan oleh variabel clinical quality assurance $\left(\mathrm{X}_{3}\right)$ sebesar 23,85 persen.

Dari perhitungan dengan analisis jalur di atas maka diperoleh koefisien determinasi sebesar 78,35 persen yang merupakan pengaruh gabungan dari variabel physical facilities, guest relations programs dan clinical quality assurance terhadap kepuasan pasien atau lebih jelasnya bahwa pengaruh variablevariabel di atas terhadap kepuasan pasien adalah sebesar 78,35 persen sedangkan sisanya dipengaruhi oleh variabel- variabel lain yang tidak diteliti yaitu sebesar 21,65 persen.
Pengujian Hipotesis Pengujian hipotesis pertama

1) Pengujian koefisien jalur secara keseluruhan

Dengan menggunakan tingkat keyakinan sebesar $95 \%(\alpha=0,05)$ dan derajat kebebasan atau degree of freedom $(\mathrm{df})=\mathrm{k}$ dan $(\mathrm{n}-\mathrm{k}-1)$ diperoleh $\mathrm{F}$ tabel sebesar 2,7253 atau dibulatkan 2,72, sedangkan dari perhitungan uji $F$ menghasilkan $F$ hitung sebesar 103,7197, berarti F hitung lebih besar dari $\mathrm{F}$ table, maka hipotesis pertama yang menyatakan bahwa physical facilities $\left(\mathrm{X}_{1}\right)$, guest relations programs $\left(\mathrm{X}_{2}\right)$ dan clinical quality assurance $\left(\mathrm{X}_{3}\right)$ secara keseluruhan atau bersama-sama mempunyai pengaruh yang berarti terhadap kepuasan pasien $(\mathrm{Y})$ dapat diterima.

2) Pengujian koefisien jalur secara parsial

Dengan menggunakan tingkat keyakinan sebesar 95\% $(\alpha=0,05)$ dan derajat kebebasan atau degree of freedom $(\mathrm{df})=\mathrm{k}$ dan $(\mathrm{n}-\mathrm{k}-1)$ diperoleh $\mathrm{t}$ tabel sebesar 1,9913 atau dibulatkan 1,99 sedangkan dari hasil perhitungan uji $t$ menghasilkan $t$ hitung untuk masing-masing variabel adalah seperti pada tabel 10 .

Tabel 10 Keberartian koefisien jalur secara parsial

\begin{tabular}{lcll}
\hline variabel & t hitung & $\begin{array}{l}\mathbf{t} \text { tabel } \\
\text { df } \mathbf{0 , 0 5} \\
\mathbf{( 3 , 8 6 )}\end{array}$ & $\begin{array}{l}\text { Keputusan } \\
\text { thd Ho }\end{array}$ \\
\hline X1 & 4,1576 & 1,9913 & ditolak \\
$\mathbf{X 2}$ & 6,3799 & 1,9913 & ditolak \\
$\mathbf{X 3}$ & 5,6131 & 1,9913 & ditolak \\
\hline
\end{tabular}

Dari tabel 10 dapat dilihat bahwa dari hasil perhitungan diketahui $\mathrm{t}$ hitung untuk variabel physical facilities $\left(\mathrm{X}_{1}\right)$ ternyata lebih besar daripada t tabel yaitu sebesar 4,1576 sedangkan $t$ tabel adalah sebesar 1,9913 maka 
dapat dikatakan secara parsial physical facilities mempunyai pengaruh yang berarti terhadap kepuasan pasien (Y), t hitung untuk variabel guest relations programs $\left(\mathrm{X}_{2}\right)$ ternyata lebih besar daripada $\mathrm{t}$ tabel yaitu sebesar 6,3799 sedangkan t tabel adalah sebesar 1,9913 maka dapat dikatakan secara parsial guest relations programs mempunyai pengaruh yang berarti terhadap kepuasan pasien (Y), t hitung untuk variabel clinical quality assurance $\left(\mathrm{X}_{3}\right)$ ternyata lebih besar daripada $\mathrm{t}$ tabel yaitu sebesar 5,6131 sedangkan t tabel adalah sebesar 1,9913 maka dapat dikatakan secara parsial clinical quality assurance mempunyai pengaruh yang berarti terhadap kepuasan pasien (Y). Dari hasil di atas maka maka hipotesis pertama yang menyatakan bahwa physical facilities $\left(\mathrm{X}_{1}\right)$, guest relations programs $\left(\mathrm{X}_{2}\right)$ dan clinical quality assurance $\left(\mathrm{X}_{3}\right)$ secara parsial mempunyai pengaruh yang berarti terhadap kepuasan pasien (Y) dapat diterima.

\section{Pengujian hipotesis kedua}

Untuk menguji variabel bebas (independen) yang paling berpengaruh diantara variabel physical facilities $\left(\mathrm{X}_{1}\right)$, guest relations programs $\left(\mathrm{X}_{2}\right)$ dan clinical qualityassurance $\left(\mathrm{X}_{3}\right)$ terhadap kepuasan pasien (Y) dapat diketahui dari besarnya nilai koefisien jalur dari masing-masing variabel tersebut. Dari hasil perhitungan diketahui bahwa besarnya koefisien jalur untuk variabel physical facilities $\left(\mathrm{PYX}_{1}\right)$ adalah sebesar 0,2847 , koefisien jalur untuk variabel guestrelations programs $\left(\mathrm{PYX}_{2}\right)$ sebesar 0,4298 dan koefisien jalur untuk variabel clinical quality assurance $\left(\mathrm{PYX}_{3}\right)$ sebesar 0,3403, dengan demikian terlihat bahwa koefisien jalur untuk variabel guest relations programs $\left(\mathrm{PYX}_{2}\right)$ lebih besar daripada koefien jalur untuk variabel physical facilities $\left(\mathrm{PYX}_{1}\right)$ dan koefisien jalur untuk variabel clinical quality assurance $\left(\mathrm{PYX}_{3}\right)$ sehingga hipotesis yang menyatakan bahwa guest relations programs secara langsung mempunyai yang paling besar dibandingkan dengan physical facilities dan clinical quality assurance dapat diterima.

\section{KESIMPULAN}

Physical facilities, guest relations programs dan clinical quality assurance secara keseluruhan mempunyai pengaruh yang berarti terhadap kepuasan pengguna jasa pelayanan rawat inap pada Rumah Sakit Pertamina Cilacap yang dibuktikan dengan hasil perhitungan yang menunjukkan bahwa $\mathrm{F}$ hitung sebesar 103,7197 lebih besar dari $\mathrm{F}$ tabel sebesar 2,7253. Kecenderungan pengguna pelayanan jasa dalam memperoleh kepuasan yang dipengaruhi oleh ketiga variabel diatas secara ekonomi dapat kita ketahui dari besarnya total pengaruh gabungan ketiga variabel tersebut yaitu 20,95 persen ditambah 33,54 persen ditambah 23,86 persen hasilnya 78,35 persen, artinya bahwa 78,35 persen tingkat kepuasan yang diperoleh pengguna pelayanan jasa rawat inap pada Rumah Sakit pertamina Cilacap dipengaruhi oleh variable-variabel diatas, sedangkan pengaruh variabel lain yang tidak diteliti terhadap kepuasan pengguna pelayanan jasa rawat inap pada rumah sakit Pertamina Cilacap adalah sebesar 46,53 persen. 
Guest relations programs secara parsial mempunyai pengaruh paling besar terhadap tingkat kepuasan pengguna jasa pelayanan rawat inap pada Rumah Sakit Pertamina Cilacap yang dibuktikan dengan hasil perhitungan yang menunjukkan bahwa koefisien jalur untuk guest relations programs sebesar 0,4298 lebih besar dibandingkan dengan koefisien jalur untuk physical facilities sebesar 0,2847 dan clinical quality assurance sebesar 0,3403. Secara ekonomi dapat diartikan bahwa guest relations programs yang diperoleh pengguna pelayanan jasa secara langsung akan dapat berpengaruh pada kepuasan pasien sebesar 18,47 persen sedangkan pengaruh melalui hubungannya dengan physical facilities sebesar 7,82 persen dan pengaruh melalui hubungannya dengan clinical quality assurance sebesar 7,25 persen sehingga total guest relations programs akan dapat mempengaruhi tingkat kepuasan pengguna pelayanan jasa rawat inap sebesar 33,54 persen.

\section{DAFTAR PUSTAKA}

Al Rasyid, Harun. 1994. Teknik pengambilan sampel dan penyusunan skala. Program pasca sarjana Universitas Padjadjaran. Bandung.

Assauri, Sofyan. 1991. Pemasaran dan kebijaksanaan promosi rumah sakit. Usahawan No. 03 Th XX. Jakarta.

Fish T. A et. al., 1990. Creating patient satisfaction and loyalty. Journal of health care marketing.

Gasperz, Vincent. 1997. Manajemen kualitas dalam industri jasa. Yayasan Indonesia emas dan
Gramedia pustaka utama. Jakarta.

Kartini Kartono. 1996. Pengantar Metodologi Riset Sosial. Mandar Maju . Bandung

Sitepu, Nirwana SK. 1994. Analisis jalur. FMIPA Universitas Padjadjaran. Bandung.

Soejadi. 1996. Pedoman Penilaian Kinerja Rumah Sakit Umum. Katiga Bina. Jakarta

Supranto, J. 1997. Pengukuran tingkat kepuasan pelanggan untuk menaikkan pangsapasar. Rineka Cipta. Jakarta.

Supranto, J. 1997. Metode riset aplikasinya dalam pemasaran. Rineka cipta. Jakarta.

Tjiptono, Fandy. 1994. Strategi pemasaran. Andi offset. Yogyakarta.

Umar, Husein. 2000. Riset pemasaran dan perilaku konsumen. Gramedia Pustaka Utama. Jakarta. 